\title{
GABRIELA MISTRAL: \\ LA ACEPTACIÓN DEL DOLOR NECESARIO. ENSAYO PARA UNA POÉTICA Y NOTICIA DE LOS POEMAS QUE PUBLICÓ EN GALICIA
}

\author{
Por \\ EVA VALCÁRCEL
}

\begin{abstract}
Al pensar en escribir sobre Gabriela Mistral como mujer y como poeta, no dejo de recordar unas contundentes palabras suyas sobre el conocimiento de los otros «...nadie comprende a nadie y por lo tanto nadie debe tratar de explicar a nadie» ${ }^{1}$. Acepto este razonamiento y lo asumo, y aún así trataré de explicar mi lectura de la propia explicación de sí que esta severa y gran mujer ensayó en su poesía.

Además de esta cita, aún hay dos imágenes de Gabriela que me persiguen cuando me acerco a cualquiera de sus textos. Veo a la pequeña maestra adolescente, casi una niña, enfrentada al juego o ejercicio de vivir, con las dificultades de la mujer sola que creó su propia vida con tenacidad insospechada. La misma mujer de quien, en 1957, en un acto de homenaje ${ }^{2}$
\end{abstract}

\footnotetext{
${ }^{1}$ Esta cita es elegida también por Jaime Concha para el inicio de su libro Gabriela Mistral, Júcar, Serie Los Poetas, Madrid, 1987.

${ }^{2}$ Los días 11 y 12 de diciembre de 1995, La UNESCO acogió en su sede de París un Homenaje a Gabriela Mistral en el cincuenta aniversario de su Premio Nobel. La Delegación Permanente de Chile, al frente de la que se encontraba en ese momento el escritor Jorge Edwards, organizó el acto, en el que pudimos descubrir aspectos inéditos de la
}

"CUADERNOS DE ESTUdios GALLEGOS", Tomo XLIV, Fascículo 109, Santiago 1997. 
en Washington, alguien - Rafael Heliodoro Valle - que la había conocido y que la admiraba, dijo «...era alta, silenciosa y huraña. Tenía una sonrisa inesperada que la tornaba infantil» ${ }^{3}$. Es un retrato sintético y agudo, nos acerca a una mujer entregada a su experiencia interior, pero una mujer al cabo niña - ¿niña de cera?

Hace poco tiempo he podido leer un monólogo en dos actos, estrenado en Helsinki este mismo año, en el que se retrataba a la poeta el 29 de diciembre de 1956, pocos días antes de su muerte. El perfil de la monologante era el de una mujer, con una sofocante biografía de la que no puede despegarse y el de una escritora que recibe su aliento diario del acto de sublimar su propia existencia, su dolor y sus carencias, su frustración maternal o mística, mediante la escritura. Las diferentes Gabrielas me parecieron muy coherentes, muy iguales. La Gabriela monologante es la Gabriela de Romelio, la de YinYin, la del Premio Nobel, la herida Gabriela de las plegarias, la que desea morir, pero también es la mujer dulce que, a solas, puede recuperar la infancia sin esfuerzo, cuando percibe en su cuarto y en sus entrañas la presencia de su madre muerta mientras escribe los versos de «Muerte de mi madre». La complicidad biológica entre madre e hija, es elaborada por Maritza Núñez, la autora de esta pieza teatral,

personalidad de esta escritora, docente y política, aportados por críticos y artistas, como Roberto Valdés, Jaime Quesada, Federico Schopf... De mi participación como invitada en el acto procede en parte este ensayo.

${ }^{3}$ El Departamento de Asuntos Culturales de la Unión Panamericana recogió en folleto diversos trabajos en homenaje a Gabriela Mistral, bajo el título Gabriela Mistrál (1889-1957). De este modo se dio cumplimiento a la resolución aprobada por el Consejo de la Organización de Estados Americanos del 18 de enero de 1957 que dispuso: «Auspiciar la iniciativa de la Unión Panamericana para realizar una velada literaria como tributo a la memoria de Gabriela Mistral».

La velada tuvo lugar el 8 de febrero de 1957, en el Salón de las Américas de la Unión Panamericana, en Washington. La publicación de los textos está fechada en la misma ciudad en 1958. Los trabajos publicados en folleto son los que siguen: «Recuerdo de Gabriela Mistral», de Juan Marín, «Gabriela Mistral: aspectos de su vida y de su obra», por Juan Uribe Echevarría, «Alabanza de Gabriela Mistral», de Rafael Heliodoro Valle, «Las ideas americanistas de Gabriela Mistral» de José A. Mora y «Los escritos de Gabriela Mistral y estudios sobre su obra», de Norah Albanell y Nancy Mango.

${ }^{4}$ Niña de cera. Monólogo en dos actos, es el título de una pieza teatral de Maritza Núñez (Lima, 1958) representada en el teatro Jurkka de Helsinki en enero de 1995. La edición del texto estuvo a cargo del Teatro Jurkka, Amici Instituti Iberoamericani y Universidad de Helsinki.

"CUADERNOS DE ESTUDIOS GALLEGOS", Tomo XLIV, Fascículo 109, Santiago 1997. 
mediante una anécdota de gran belleza desgranada del inicio del poema «Madre mía, en el sueño / ando por paisajes cardenosos...» («Muerte de mi madre, Tala).

La cita es ésta:

(se detiene y, después de permanecer pensativa unos instantes, continúa con dulzura).

«Mamá, ¿te acuerdas de aquella vez, cuando la lluvia nos inundó la casa?. Yo tendría seis años. Mientras tú tratabas de detener el agua yo te ayudaba a secar el piso. Tú y yo, solas, y completamente mojadas. ¿Qué rato! De pronto, me preguntaste agobiada, ¿qué hacemos, Lucila? ¿Lloramos o nos sentamos a comer naranjas? Y yo sin dudarlo te respondí, ¡sentémonos a comer naranjas!»5.

En mi opinión, esta Gabriela dulce y luminosa en sus recuerdos es la misma Gabriela áspera que aparece en sus poemas, en el poema citado, Madre mía, en el sueño... El ser retorcido por la vida y por la presencia de un dolor imbatible y extenso - «El sabor del cuerpo, que es la vida, es el mismo sabor de la sangre, que es la vida, es el mismo sabor de la lágrima, que es el dolor»- que asume como necesidad, con una aceptación esencialmente femenina, originada en la propia fisiología de la mujer, que determina su comportamiento. El dolor marca su propio estilo literario, persiste en la elaboración metafórica, en la ausencia de brillo, en la sencillez buscada con vocación ascética y lograda como humilde desposesión y acercamiento a Dios. Su poesía es rítmica, pero es sobria, es contenida en su dramatismo. El yo lírico no grita ni trata de huir de la desgracia, sino que prefiere explicarla y aceptarla como posible vía de ascensión espiritual. Bebe el cáliz amargo. El martirio no es buscado, pero no es posible obviarlo. Como poeta está perfectamente instalada en el mundo de la carne, la sangre y las materias. Los objetos y los episodios vividos, los elementos de la naturaleza están poetizados en sus versos porque comunican con Dios, son intermediarios, y Él es el hombre sumo, el que más ha padecido, el que ha aceptado el dolor. Las materias, los objetos, las anécdotas llevan al ejemplo del Hijo de Dios, de aquél que es invoca-

\footnotetext{
${ }^{5}$ Niña de cera, ed. cit., p. 31.
} 
do dramáticamente, y sin el intermedio de reflexión matafísica alguna, en su «Nocturno» («Dolor», Desolación), el que no quiere mirarla. Ella, la abandonada del Padre, el ser solitario de la creación, ruega e interroga:

«Padre Nuestro que estás en los cielos / ¿porqué te has olvidado de mí?».

Aunque la espiritualidad profunda forma parte esencial de sus versos, su sentimiento de desposesión no es el de un místico y sus poemas nunca persiguen el silencio sino una explicación, una mirada, una respuesta que le sirva para seguir aceptando su vida y la de los otros. No hay silencio ni tregua para ella, por lo tanto, no se puede dar la experiencia de la desposesión absoluta que posibilita en el hombre el receptáculo de Dios.

El dolor y la espiritualidad de esta poeta son activos, intensos, orantes y exigentes. No hay espacio para el no hacer, para el aposentarse del Dios. La insuficiencia de la palabra convencional que conduce al místico - a San Juan de la Cruz, por ejemplo— a la conciencia del límite, aceptando de la palabra su dimensión significante limitada, primaria, como la materialidad que aloja un segundo significante entrevisto, prometido más alla del límite, es resuelta en Gabriela Mistral con el instrumento de la innovación poética, con la utilización de una lengua en ebullición que no se detiene ante el riesgo de cruzar los umbrales de lo ortodoxo, de lo convencionalmente bello. Para el místico, el lenguaje funde lo racional y lo irracional y se expresa como sentimiento después de haberse elaborado como abstracción. Gabriela Mistral en su camino espiritual desprende la existencia del mundo absoluto sólo después de la reflexión sobre las cosas, sobre el concepto que de ellas se desprende. Gabriela ve las cosas, experimenta su grandeza y se vuelve hacia lo espiritual, pero no se entrega sin preguntas a la contemplación, al Amado, como lo hace San Juan, hay en ella, además de emoción, una marca racional que proviene tal vez de su profesión primera de maestra, de su compromiso con el mundo, y que necesita una explicación, un ordenamiento propio de las convulsiones experimentadas.

Su alma es desconocida para ella misma y todos sus actos son realizados por medio de las potencias, la voluntad de amar, la imaginación al recordar, la razón para conocer. Siguiendo al Maestro Eckhardt, podríamos concluir que, también para Gabriela Mistral conoce el alma cual- 
quier objeto, pero no a sí, ya que carece de intermediario. «El místico, — decía la poeta - es casi siempre, mitad ardor, mitad confusión; es el hombre que entra como en una nube ardiente que lo lleva arrebatado».

El Dios de los poemas de Mistral, es el hijo de Dios que vivió en el mundo, un Dios que posee una parecida experiencia del dolor humano; en los versos se nos habla de su gran aflicción, es «un Dios sin ardor y sin canto...», desalentado Dios, «un Dios de otoño», — llega, en este poema, a la imagen de Dios mediante el intermediario de la naturaleza, contenida en una imagen «la alameda en otoño»— un Dios frágil, al borde de las lágrimas, desprotegido y doméstico:

«Y pienso que tal vez Aquél tremendo y fuerte

Señor, al que cantara de locura embriagada

no existe y que mi Padre que las mañanas vierte tiene la mano laxa, la mejilla cansada».

Me propongo ahora recorrer la poesía de Mistral y detenerme, siquiera fugazmente, en unos pocos gestos poéticos que justifican mi ejercicio de comprensión de la autora.

Me detengo en el mismo «Nocturno», ya citado, perteneciente a «Dolor»(Desolación).

El poema se entrega como una plegaria, con un ritmo suave y fluyente. Pero me interesa destacar sobre todo que esa oración elevada por el sujeto lírico cambia de signo cuando el orante se identifica con el dolor del Hijo de Dios y parece rogar con Él: «Padre, aparta (también) de mi éste cáliz». En el poema, el sujeto lírico acepta finalmente la purificación mediante la penitencia, y una vez concluida, se manifiesta dispuesta a beber el cáliz amargo, a morir: «Ahora suelto la mártir sandalia / y las trenzas pidiendo dormir». Implora la mirada de Dios, una mirada que reconozca su redención, su madurez como fruta:

«Padrenuestro que estás en los cielos, ¿por qué te has olvidado de mí?

Te acordaste del fruto de Febrero,

"CUADERNOS DE ESTUDIOS GALLEGOS", Tomo XLIV, Fascículo 109, Santiago 1997. 
al llegarse su pulpa rubí.

¡Llevo abierto también mi costado, y no quieres mirar hacia mí!» ${ }^{6}$.

Este poema introduce dos veces el sustantivo «lagar», «lagar carmesí» y «lagar de la muerte», consiguiendo una imagen muy efectiva: lagar, camino de purificación de la carne exprimida de la uva, lagar de la muerte, lugar de abandono del cuerpo para la purificación es cuerpo exprimido como fruta. La creación parece ser «estrofa exprimida».

«Y he apretado la boca, anegada

de la estrofa que no he de exprimir...»

Por otro lado, persiste y gravita sobre los versos la iconografía bíblica, el vino eucarístico o la sangre, la pasión de Cristo.

La imagen del lagar como espacio de la purificación alcanza su verdadero sentido en el último poemario de Gabriela, en el que se recoge la nada o el humo después de las cenizas del abrasado cuerpo. En el poemario trágico, de acabamiento definitivo, el poema ya no ofrece luz alguna, se yergue sobre la laceración y termina en carne viva.

La lectura de «El pensador de Rodin» (Desolación) nos acerca a algunas imágenes poéticas que caracterizan la cosmovisión agónica de Mistral. Es éste un poema de carpe diem, con resonancias de Jorge Manrique o de Rosalía de Castro, o de Quevedo. Y posee ecos de «Lo fatal» de Darío, pero es un poema profundamente original también.

Gabriela Mistral participa de una experiencia poética común a todos los hombres, el paso del tiempo; pero en la experiencia poemática introduce su marca personal: el tratamiento del cuerpo, exento de toda sensualidad, placer o goce, el cuerpo funcional. Con una escueta "primavera ardiente» y un «tembló de amor y de belleza» se alude a la vida que no presagia aún la muerte, la frialdad del metal, «el agudo bronce» en el poema describe la geografía humana en sus distintos niveles de relieve. El destino de la carne mortal se desvela mediante el gesto adusto de «la

${ }^{6}$ Los poemas se citan por el texto Poesías Completas, Ed. de Margaret Bates y Esther de Cáceres, Aguilar, Madrid, 1966, (Tercera edición).

"CUADERNOS DE ESTUDIOS GALLEGOS", Tomo XLIV, Fascículo 109, Santiago 1997. 
mano ruda», la mano elegida reiteradas veces como gesto vivo y como imagen poética. La mano que simboliza la actividad, la fuerza, la manifestación. La mano, como el ojo, transmite el conocimiento, por la forma o la visión.

De la mano a la carne abierta, al músculo enterrado; las heridas, son los surcos que en la carne abrigan la semilla de la muerte:

«Y en la angustia, sus músculos se hienden, sufridores.

Los surcos de su carne se llenan de terrores».

Dramatismo del hombre desgarrado por la herida de la muerte que separa carne y músculos, mutilando a cada uno en ese acto.

«Luto» es un poema de Lagar que responde a un sentimiento de profunda disolución del ser en la consumación del dolor tantas veces ejecutado. Transido de un dolor tan profundo que arrebata el cuerpo y con él la posibilidad misma del dolor, signo de la vida al fin, el cuerpo es anulado, — «Dónde me palpan ahora?»— invadido por la enfermedad, y desaparece junto a su rastro. Los versos no dejan ninguna esperanza de fuga, acentúan un concepto poético hasta agotar su materia significadora:

«Igual que las humaredas

ya no soy llama ni brasas.

Soy esta espiral y esta liana

y este ruedo de humo denso».

Parece el cuerpo, pero no es. Su silueta de humo no se puede tocar, se difumina en el aire. Se ve, pero la vista miente. Gabriela subraya su fe en lo matérico, lo táctil: «ciprés engañoso, / cierto a los ojos, huido en la mano».

La muerte en vida, el cuerpo convertido en tumba. El intenso dolor, más intenso porque es aceptado, es expuesto como un avatar irreversible del destino propio, y borra los contornos de ser que se disuelve y pierde su existencia temporal. La percepción del tiempo se refleja en los versos:

«El color se escapó de mis ropas,

el blanco, el azul se huyeron...»

"CUADERNOS DE ESTUDIOS GALLEGOS", Tomo XLIV, Fascículo 109, Santiago 1997. 
«Un solo color en las estaciones

un sólo costado de humo

y nunca un racimo de piñas

para hacer el fuego, la cena y la dicha».

Materias es el nombre de una sección de Tala constituida por los poemas «Pan», «Sal», «Agua», «Aire» $\mathrm{y}$ «Cascada en sequedal». Éste último poema rompe, por el título, el tratamiento del tema y el ritmo, la armonía inscrita en los demás, que denominan los alimentos primordiales.

«Pan», refleja la inmersión en la memoria propia y, por medio de ella, en la memoria del mundo, en la memoria original. La primera estrofa, ofrece una imagen plástica: el pan abierto, roto, de formas impuras y entrañas abiertas, con la connotación de pan alimento, anuncio del hombre. El pan se relaciona con la vida activa y el vino con la contemplativa; por eso el gran misterio de la transformación del vino en agua en las Bodas de Canan se opone al pequeño misterio cuantitativo de la multiplicación de los panes. El tacto y el olor del pan, en el poema, sumergen la imagen plástica en la memoria profunda del alimento esencial. La visión interior prevalece sobre la imagen plástica, pero no se produce una abstracción, la memoria conduce a la emoción infinita del encuentro con la infancia y los amigos muertos, ahora momentáneamente resucitados:

«Abro la miga y les doy su calor;

lo volteo y les pongo su hálito».

El poema «Sal» tiene una estructura ideal muy parecida a «Pan». En la primera estrofa encontramos una imagen plástica, rica en formas (duna, ala, cuenco) que se interioriza y da paso a una visión imaginada:

«La sal cogida de la duna, gaviota viva de ala fresca desde su cuenco de blancura, me busca y vuelve su cabeza».

La sal es fuego sacado del agua. El grano de sal que se funde en el agua simboliza la reabsorción del yo en el ser universal. En el poema de Gabriela Mistral, la sal tiene un claro sentido de purificación y de alimen- 
to, siguiendo la liturgia cristiana. Es la sal el alimento bautismal, el signo de la fraternidad, de la sabiduría y de la penitencia:

«Me salaba los lagrimales

y los caminos de mis venas,...»

El pan y la sal, en los dos poemas, se encuadran en el espacio de «la casa», en el primer ejemplo está vacía, en el segundo es profunda y quie$t a$, y se nombra una puerta por la que se atraviesa. Es interesante notar como la poeta intensifica el sentido de estos significantes mediante la adición de motivos simbólicos. «La casa» simboliza el ser interior, pero también lo femenino, el refugio, la cocina en donde se guardan los alimentos es un lugar de transmutación, de cambio, de evolución interior. El acto de franquear la puerta tiene el mismo sentido de paso accesible entre dos estados, de viaje a lo sagrado, en Gabriela Mistral.

Para terminar, no quisiera dejar de hacer referencia a la presencia de Gabriela Mistral en Galicia. Gabriela, que no amaba mucho a España pero sí a Portugal según se desprende de algunas observaciones suyas, estuvo presente en las revistas culturales gallegas desde 1922, con las primeras versiones de sus poemas que posteriormente recopilaría en libro. En ese año, publicó «Plegaria» en la revista coruñesa Marineda. El poema se llamará «Ruego» en Desolación, después de haber sido minuciosamente reestructurado en su puntuación, en su léxico y en la composición de las estrofas. Las dos versiones de «Plegaria» están compuestas en alejandrinos de dos hemistiquios idénticos, y estructuradas en doce cuartetos con rima cruzada consonántica que varía en cada secuencia, mostrando así su filiación ruberiana.

En enero de 1925, Gabriela Mistral pasa unos días en La Coruña invitada por Julio J. Casal, el poeta uruguayo y director de una revista muy importante en la vanguardia española, la revista coruñesa $\mathrm{Alfar}^{7}$ — destacada por la difusión de los poetas o prosistas hispanoamericanos- en ella publicó Vicente Huidobro su polémica con Guillermo de Torre. Gabriela pronunciará una conferencia «Los motivos de San Francisco»y, a continuación, serán leídos tres poemas de Mistral fechados en Florencia,

\footnotetext{
${ }^{7}$ Gabriela Mistral publicó estos tres poemas en el número 16 de Alfar, año V, enero de 1925 .
}

"CUADERNOS DE ESTUDIOS GALLEGOS", Tomo XLIV, Fascículo 109, Santiago 1997. 
en 1924, que se publicarán en la revista Alfar en sus primeras versiones con los títulos de «La rosa», «Doble tesoro», recogidos en Tala y «La mano», poema inédito en libro.

«La rosa» es un poema de ofrecimiento, en el que cobra todo su significado la iconología cristiana de «la rosa» y que en otros poemas se refleja en «la copa», el Graal que recoge la sangre de Cristo. Ambas, rosa y copa, evocan la redención. El centro de la rosa, en el poema, se relaciona con la rosa de la cruz, que la iconología cristiana utiliza para simbolizar el corazón de Cristo.

La rosa es la imagen de la «dicha fiel» en «Doble tesoro», que se opone a «espina», la «dicha perdida». La dicha enfrentada a caracterizadores positivos y negativos en el mismo texto es un instrumento poético recurrente en la lírica castellana 8 .

El último poema, el que la poeta no incluyó en sus libros, es «La mano»9. Es un poema logrado escrito en combinación de endecasílabos y heptasílabos, con rimas sueltas, a la manera de la silva tradicional. El motivo poético desarrollado es recurrente y significativo en la poesía mistraliana, la mano, su mano, y la esterilidad, la asencia de manifestación que la mano supone cuando se tiende. Por lo tanto, la mano es estéril cuando ha cumplido su tiempo, como la aceituna madura o la resina desprendida como fruto. Este poema rezuma el sufrimiento de la carencia, de no haber gozado y cumplido con el rito de la fecundidad, como la Tierra lo ha hecho, como naturalmente se desprende el fruto del olivo o del pino.

El poema, de una tristeza infinita, presenta el consumado, lo fatal, lo irrecuperable y trágico de su existencia que experimenta como fraudulenta, sin goce, sin dicha, sin fruto, sin nombre de madre ni de santa. La

\footnotetext{
${ }^{8}$ Juan Uribe Echeverría, en el Homenaje de la Pan American Union 1957, leyó su conferencia titulada «Gabriela Mistral: aspectos de su vida y de su obra», en la que se refería así al parentesco de la escritora chilena con los poetas españoles:

«Gabriela desprecia la metáfora por la metáfora; la imagen por la imagen; el adorno por el brillo. Su poesía es desnuda y directa como la de Jorge Manrique, la de Antonio Machado y la de Miguel de Unamuno.

Se asemeja a Unamuno en su afán de eternidad, en la congoja mística y hasta en la sencillez, a veces rebuscada de la expresión».

${ }^{9}$ El poema será reproducido después en la revista pontevedresa Cristal, con una variante en el primer verso mediante el que se cambia la percepción temporal del hecho lirizado: «Se va secando mi mano» se transforma en «Se ha secado mi mano».
} 
«copa», símbolo que cierra el discurso del poema, recoge las dos realidades sobre las dos realidades sobre las dos verdades, y la doble e irreconciliable búsqueda del discurso poemático: el seno maternal y el Graal. Relaciona vida e inmortalidad obtenida a cambio de la muerte.

El poema es éste:

«Se ha secado mi mano como en la áspera siesta la resina y la aceituna negra en el verano.

Y no sostuve en ella

la guirnalda goteante de la dicha ni la horadó el amor como una estrella y la dejó caer dura e inerte, no alzaré en ella frutos coloreados.

(Recójanla los cestos de la muerte)

No sostendrá la copa luminosa ni la frente de un hijo.

(Recójanla los cestos de la muerte)». 


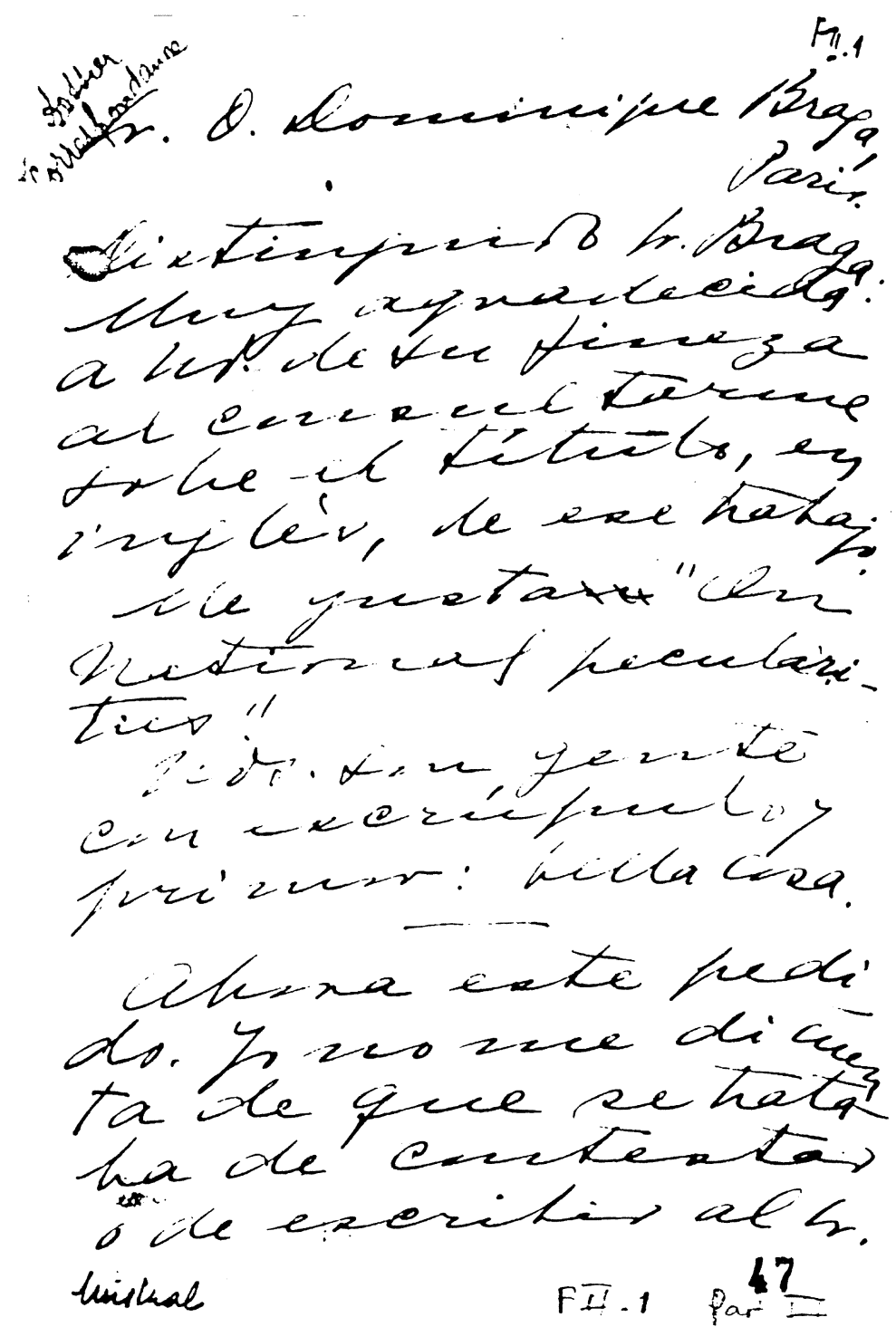

Carta autógrafa de Gabriela Mistral, fechada en Niza en 1940 y dirigida al Director del Instituto Internacional de Cooperación Intelectual, Dominique Braga. En ella, Gabriela se refiere a su ensayo Algo sobre la particularidad, que constituye su contribución a la serie de artículos que el Instituto encargó a diferentes personalidades intelectuales en los que les pedía que reflexionasen sobre la guerra y la situación sociopolítica de Europa. Entre ellos se encuentra Vicoria Ocampo, Johan Huizinga, María Gevers y los chilenos Enrique Molina y Francisco Walker Linares.

"CUADERNOS DE ESTUdiOS GALLEGOS", Tomo XLIV, Fascículo 109, Santiago 1997. 


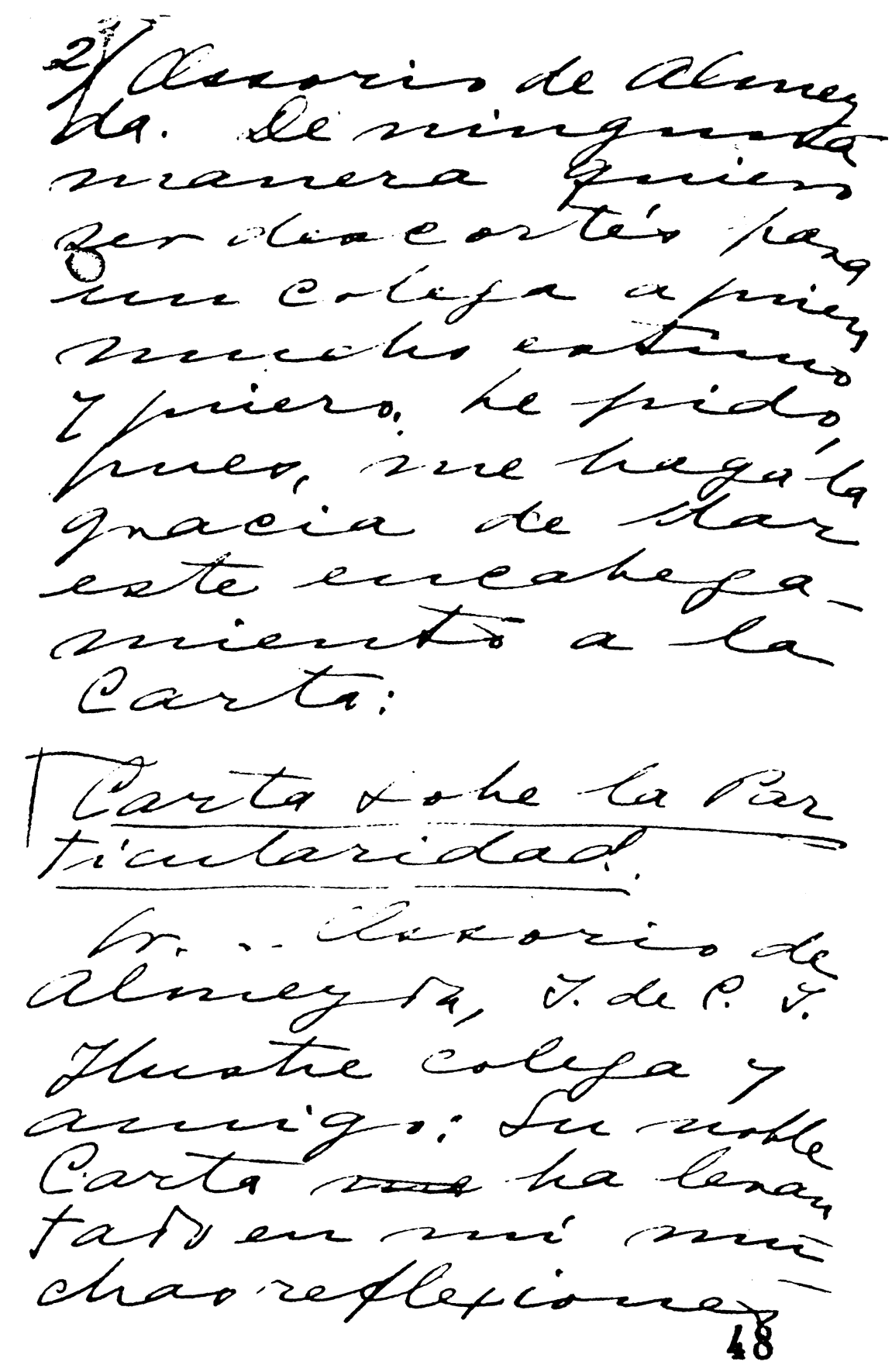

"CUADERNOS DE ESTUdios GALLEGOS", Tomo XLIV, Fascículo 109, Santiago 1997. 


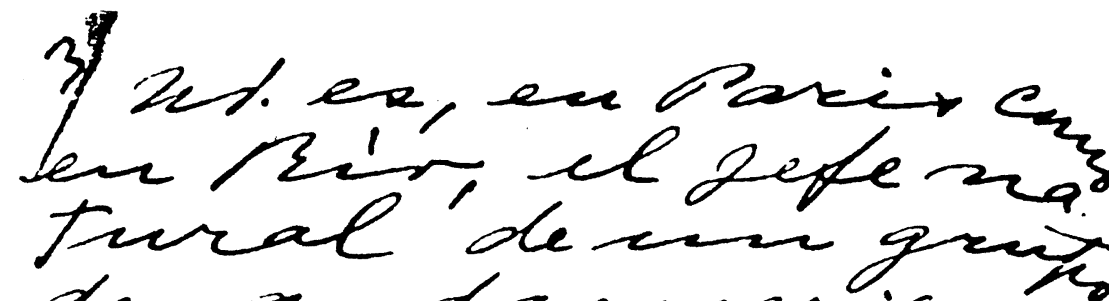

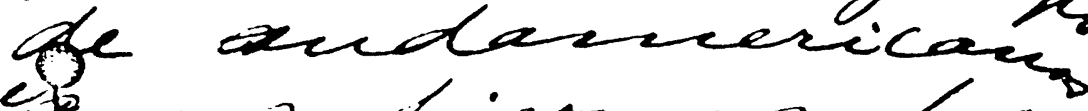

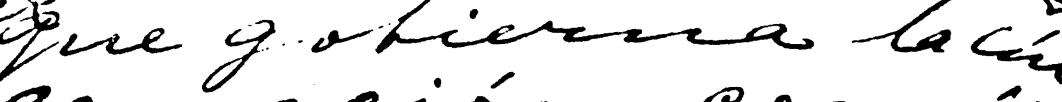

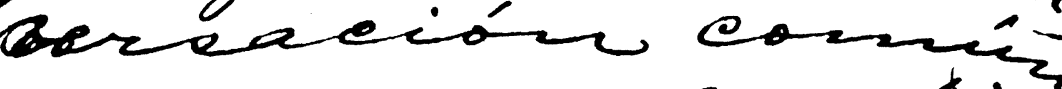

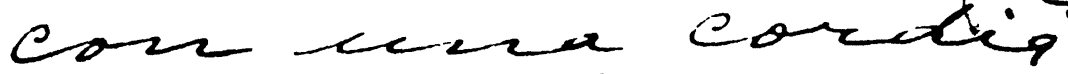

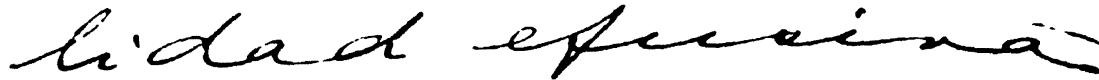

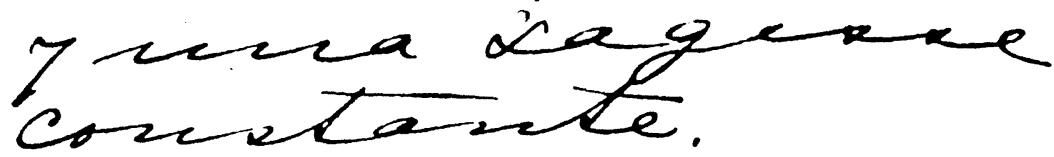

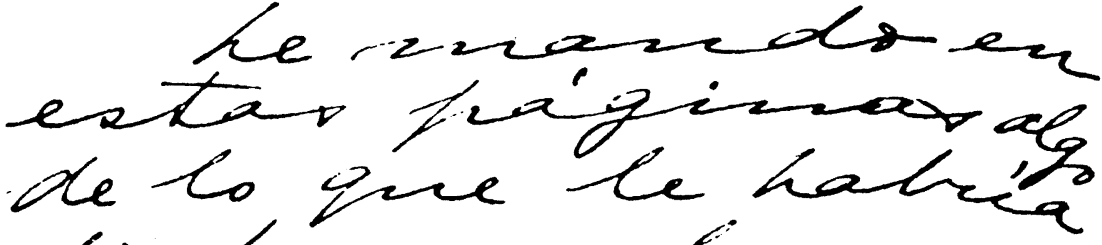

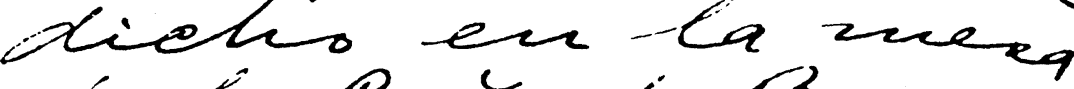

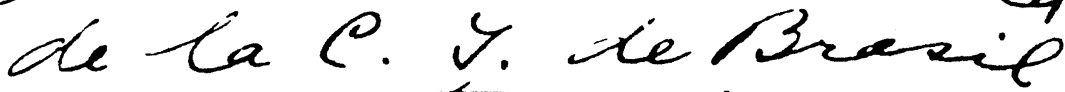

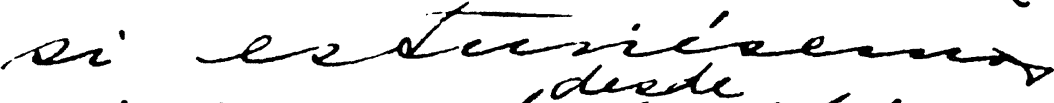

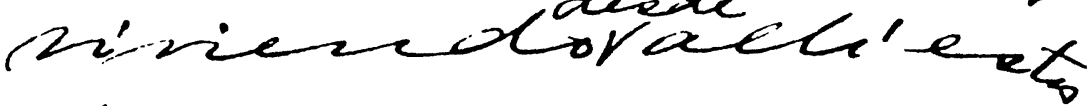

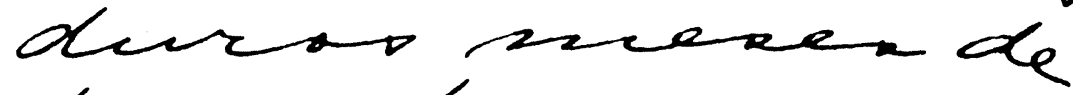

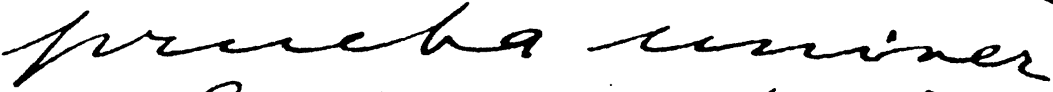

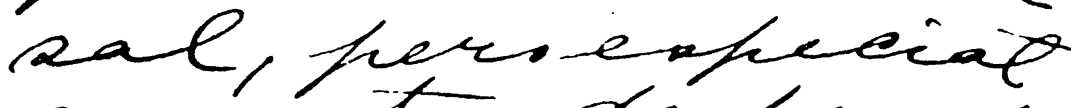

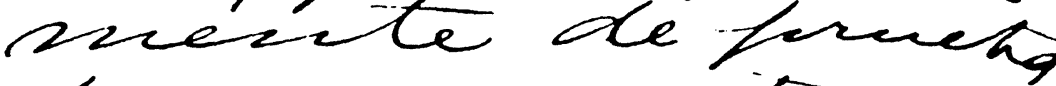

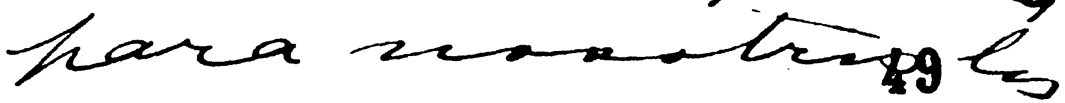

"CUADERNOS DE ESTUDIOS GALLEGOS", Tomo XLIV, Fascículo 109, Santiago 1997. 
EVA VALCÁRCEL

363

Yisterorer.

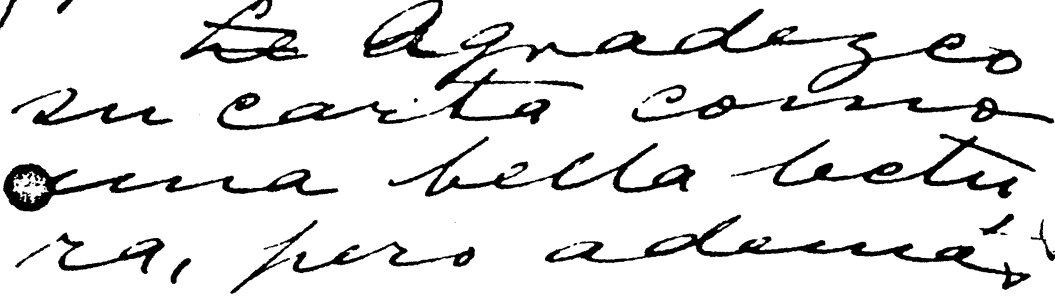
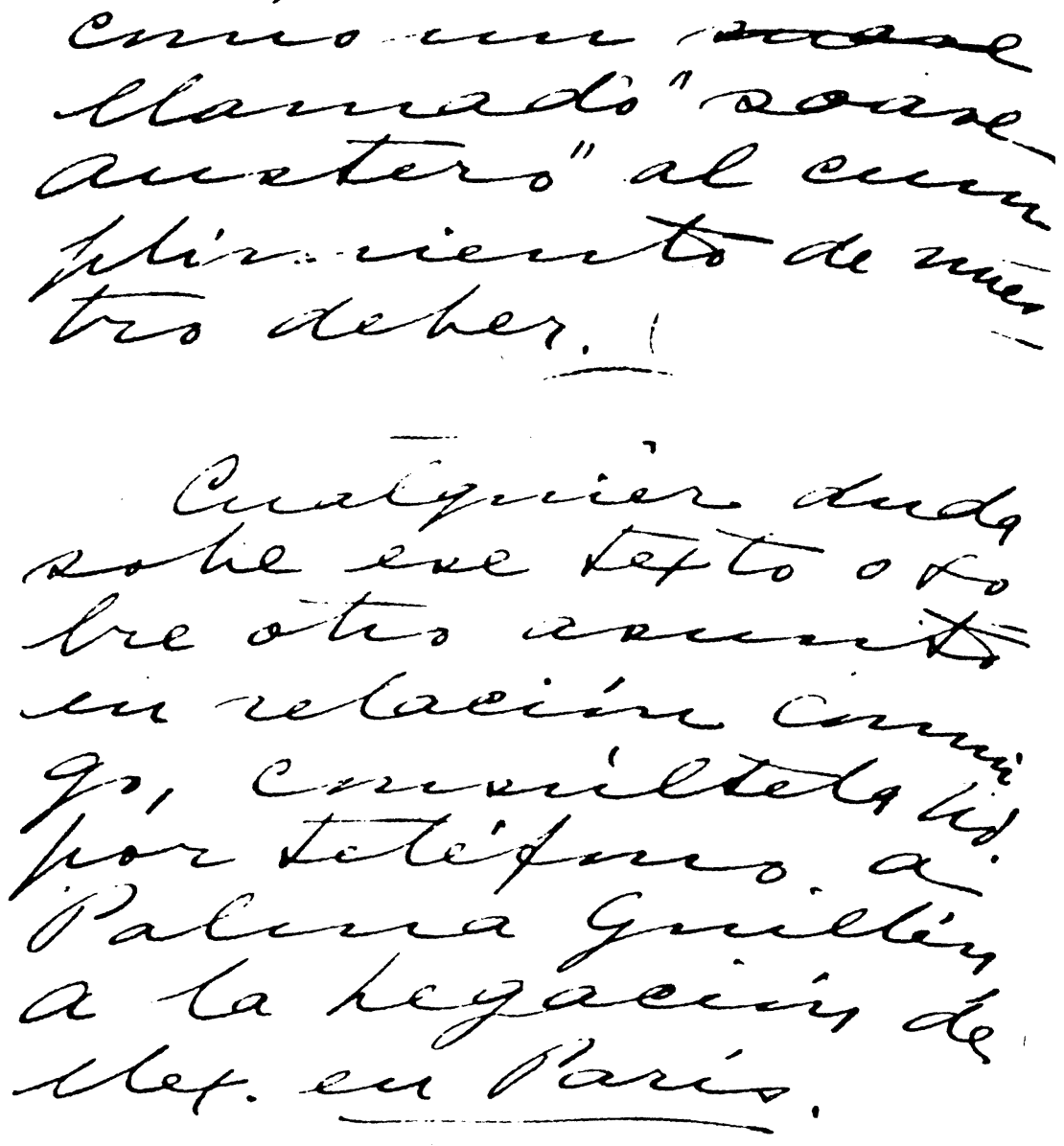

"CUADERNOS DE ESTUdIOS GALLEGOS", Tomo XLIV, Fascículo 109, Santiago 1997.

(c) Consejo Superior de Investigaciones Científicas

http://estudiosgallegos.revistas.csic.es

Licencia Creative Commons 3.0 España (by-nc) 


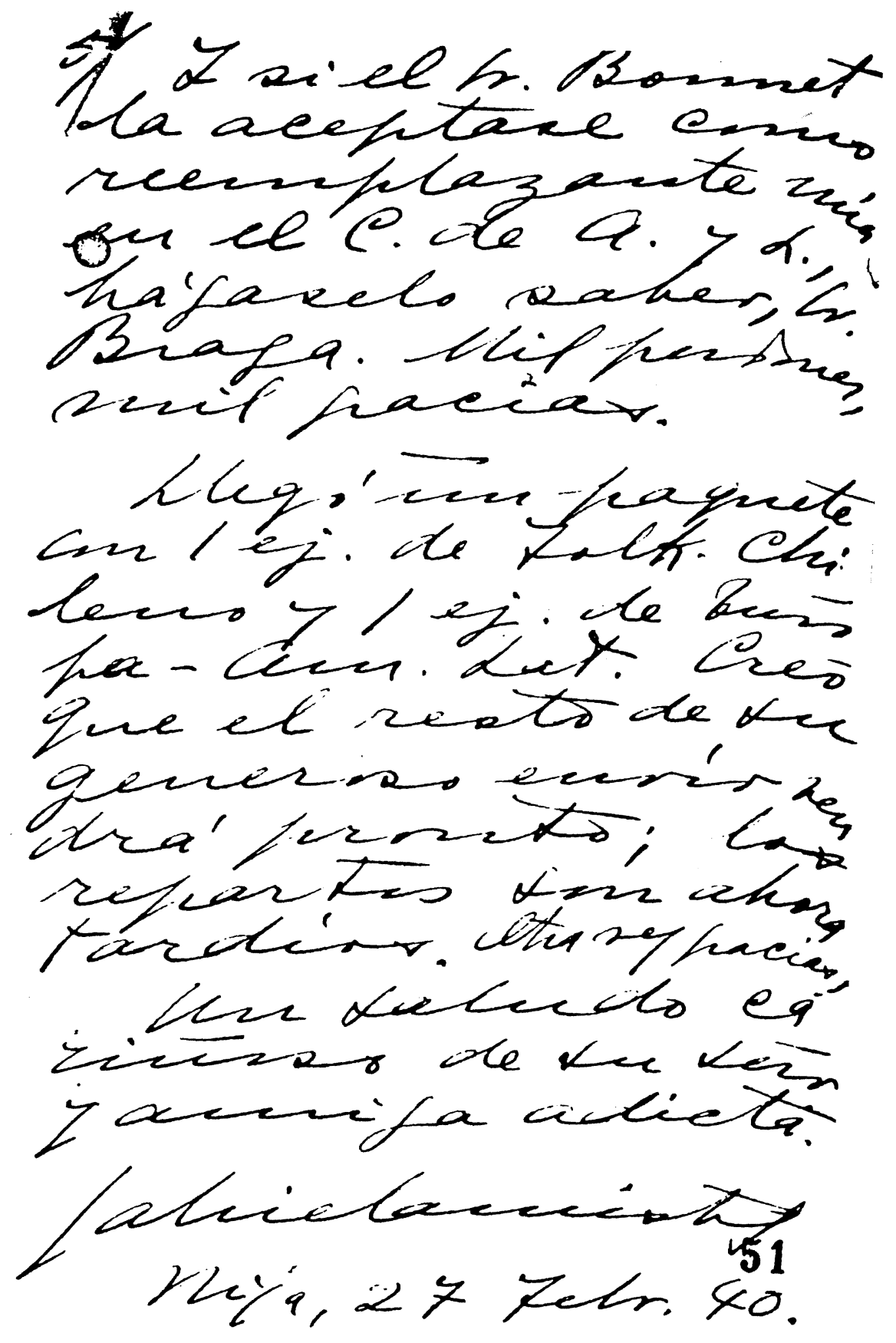

"CUADERNOS DE ESTUDIOS GALLEGOS", Tomo XLIV, Fascículo 109, Santiago 1997. 